\title{
Chemistry, ethnobotanical uses and biological activities of the lichen genus Heterodermia Trevis. (Physciaceae; Lecanorales; Ascomycota): A comprehensive review
}

\author{
T. R. Prashith Kekuda ${ }^{1 *}$, K. S. Vinayaka ${ }^{2}$, M. B. Sachin ${ }^{1}$ \\ ${ }^{1}$ Department of Microbiology, S.R.N.M.N College of Applied Sciences, N.E.S Campus, Balraj Urs Road, Shivamogga-577201, Karnataka, India. \\ ${ }^{2}$ Department of Botany, Kumadvathi First Grade College, Shimoga Road, Shikaripura-577427, Karnataka, India.
}

\begin{tabular}{|c|c|}
\hline ARTICLE INFO & ABSTRACT \\
\hline Article history: & \multirow{6}{*}{$\begin{array}{l}\text { Lichens are composite organisms comprised of a photobiont (an alga or a cyanobacterium) and a mycobiont (an } \\
\text { ascomycete or basidiomycete fungus) and represent a stable, ecologically obligate symbiotic association. The lichen } \\
\text { genus Heterodermia Trevis (Physciaceae; Lecanorales; Ascomycota) is one of the lichen genera distributed worldwide. } \\
\text { The thallus is foliose, dichotomously or irregularly branched and the genus Heterodermia differs from other foliose } \\
\text { lichen genera in the family Physciaceae mainly on the basis of its prosoplectenchymatous upper cortex in combination } \\
\text { with atranorin (a cortical lichen substance). In this review, an attempt is made to compile data (by referring books, } \\
\text { journals and various search engines such as Google Scholar, PubMed, and ScienceDirect) available on the chemistry, } \\
\text { traditional uses and biological activities of species of Heterodermia. Atranorin and zeorin are the major metabolites } \\
\text { found in Heterodermia species. Besides these, salazinic acid and norstictic acid are also found in several Heterodermia } \\
\text { species. Heterodermia species are used ethnobotanically as a flavoring agent, in preparation of perfumes and for } \\
\text { treatment of wounds and infections. Literature survey revealed the potential of extracts and isolated constituents of } \\
\text { Heterodermia species to exhibit biological activities such as antimicrobial, antioxidant, cytotoxic, antinociceptive, } \\
\text { anti-inflammatory, insecticidal, immunomodulatory and anthelmintic activity. }\end{array}$} \\
\hline Received on: $06 / 02 / 2018$ & \\
\hline Accepted on: 11/04/2018 & \\
\hline Available online: $30 / 05 / 2018$ & \\
\hline & \\
\hline $\begin{array}{l}\text { Key words: } \\
\text { Lichens, Heterodermia, } \\
\text { secondary metabolites, } \\
\text { ethnobotanical, biological } \\
\text { activities. }\end{array}$ & \\
\hline
\end{tabular}

\section{INTRODUCTION}

Lichens are composite organisms (holobionts) and represent a stable, self-supporting symbiotic relationship between a photosynthetic partner (also called photobiont, representing a microalga or a cyanobacterium) and a fungal partner (referred as mycobiont; represents the majority of the portion of lichens). They are known to be the first colonizers of the earth. Lichens are used traditionally as medicine (to cure dyspepsia, bleeding piles, bronchitis, scabies, stomach disorders, and many disorders), spice, flavoring agents (as an ingredient of garam masala, meat masala, and sambhar masala) and sources of dyes and perfumes. Traditional systems of medicine such as Ayurveda and Unani make

"Corresponding Author

T. R. Prashith Kekuda, Department of Microbiology, S.R.N.M.N

College of Applied Sciences, N.E.S Campus, Balraj Urs Road,

Shivamogga-577201, Karnataka, India.

E-mail:p.kekuda@gmail.com use of lichens (Upreti et al., 2005; Gupta et al., 2007; Nguyen et al., 2013; Shah, 2014; Behera et al., 2016). Lichens are distributed universally and occur in varied climatic conditions ranging from the poles to the tropics. They grow on various substrates such as rock (saxicolous), leaves (foliicolous), soil (terricolous), bark (corticolous) and wood (lignicolous) and exhibit one of the different growth forms such as a) crustose-spreading rapidly over the surface b) foliose-leafy and loosely attached to the surface and c) fruticose-branched and shrubby, hanging from tree twigs or branches, with a single attachment (Sanders, 2001; Pinokiyo et al., 2006; Spribille et al., 2008; Kumar, 2009).

Lichens are shown to be the best indicators of air pollution as they are very sensitive to changes in the environment and usually disappear from the area in case of pollution (Gunathilaka et al., 2011; Rodríguez et al., 2016). Lichens produce a number of secondary metabolites which seldom occur in plants, animals, and other organisms. Most of these metabolites are produced by 
mycobiont and some of the metabolites are formed only in the lichenized state. These substances are often known by name lichen substances or lichen metabolites and are small molecules with complex structure. More than 1000 of such secondary metabolites are known and are derived from acetyl polymalonyl, mevalonic and shikimate pathways (Müller, 2001; Stocker-Wörgötter, 2008; Nguyen et al., 2013). Studies on lichens have shown that solvent extracts and purified compounds exhibit potent bioactivities such as antioxidant, hepatoprotective, analgesic, antimicrobial, antiviral, cytotoxic, insecticidal, antinociceptive, anthelmintic, neuroactive, anti-inflammatory, enzyme inhibitory, immunomodularoty and anticancer activity (Müller, 2001; Karunaratne et al., 2005; Oksanen, 2006; Verma et al., 2008a; Russo et al., 2012; Brisdelli et al., 2013; Córdova et al., 2013; White et al., 2014; Thadhani et al., 2015; Reddy et al., 2016).

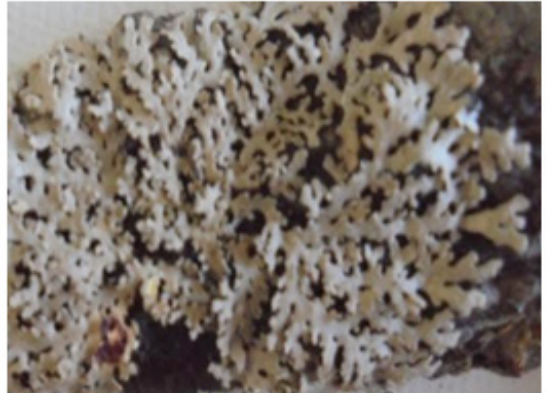

H. angustiloba

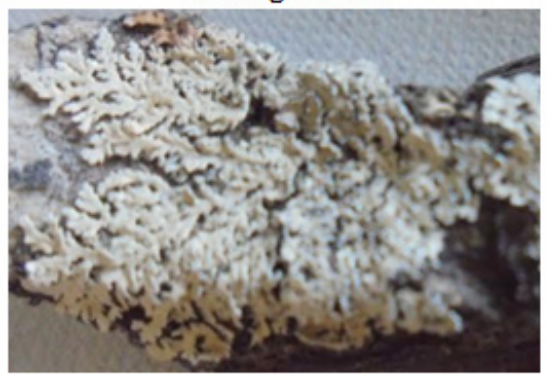

H. dissecta

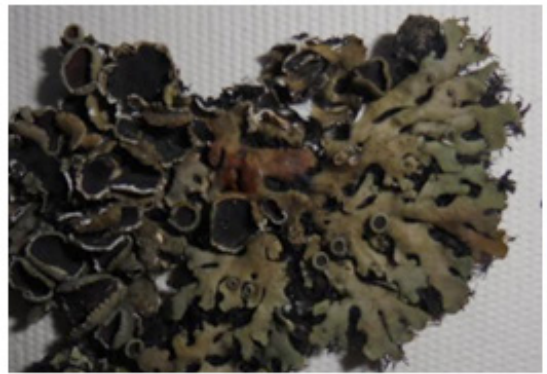

H. microphylla

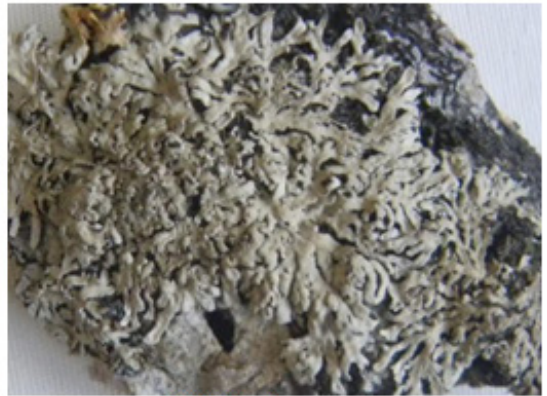

H. diademata

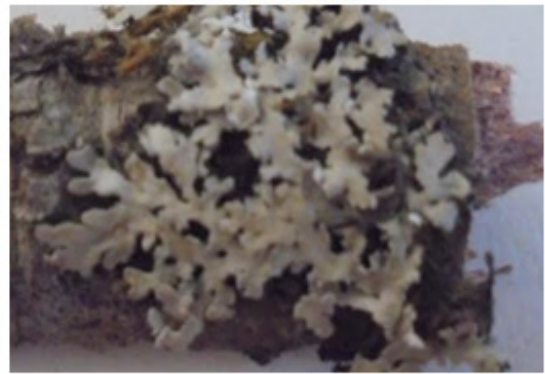

H. speciosa

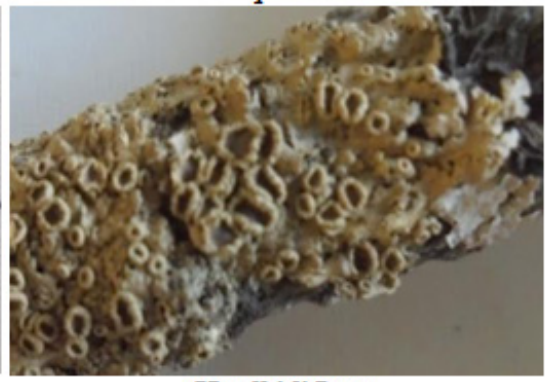

H. albidiflava

Fig. 1: Some Heterodermia species (Photographs by Vinayaka K.S).

\section{THE GENUS HETERODERMIA}

The lichen genus Heterodermia Trevis. (Physciaceae; Lecanorales; Ascomycota) is one of the most commonly found foliose macrolichens (Figure 1) found distributed in tropical and subtropical regions. Earlier, all species of Heterodermia were included in Anaptychia Körb. until thick-walled spores and the presence of atranorin were considered as useful characters for separating these two genera. The genus Heterodermia is distinguished from other foliose lichen genera in the family Physciaceae chiefly on the basis of its prosoplectenchymatous upper cortex in combination with atranorin (as a cortical lichen substance). Most Heterodermia species are also characterized by the production of abundant marginal cilia (that resembles rhizenes), lack of a lower cortex and the presence of norstictic and salazinic acids as the common medullary substances. Thallus of Heterodermia is foliose, adnate, suberect, rosulate to pendulous, irregularly or dichotomously branched, heteromerous and corticated on the upper side or both sides. The upper cortex is unevenly or uniformly thick. The photobiont is a green alga. Apothecia are laminal, sessile to pedicellate; asci 8-spored; ascospores 2-celled (Awasthi, 2007; Luckling et al., 2008; Wang et al., 2008; Wei et al., 2008). Some species of Heterodermia are used traditionally in certain countries as medicine and as spice and flavoring agent (Upreti et al., 2005; Rawat, 2016). In this review, we focus on traditional uses, chemistry and biological activities of Heterodermia species. A detailed and extensive literature survey was carried out on various aspects of the lichen genus Heterodermia by referring standard flora, journals, and 
various search engines including Google Scholar, PubMed, and ScienceDirect.

\section{ETHNOBOTANICAL USES OF HETERODERMIA SPECIES}

Lichens have traditional uses worldwide. Some species of Heterodermia find potential use in the form of medicine and flavoring agents and in the preparation of perfumes. The ethnic group in Sikkim uses $H$. diademata traditionally and applies the thalli on the cuts for protecting from wetting and infection (Upreti et al., 2005). The ethnic communities in Madhya Pradesh, India make use of $H$. tremulans as spice and flavoring agent for meat and vegetables (Upreti et al., 2005). Together with Parmotrema, $H$. diademata is traditionally used as flavoring agent for meat and other food items in Karnataka, India. It is also used medicinally to heal cuts and wounds and is used as a plaster to protect the wound from infection (Vinayaka and Krishnamurthy, 2012). The traditional industries in Uttar Pradesh, India utilize Heterodermia species viz. $H$. diademata and $H$. boryi in the preparation of perfumes (Singh et al., 2015). The ethnic communities in Nepal use $H$. diademata for treatment of wound and to stop bleeding after the injury. The lichen is mixed with Artemisia vulgaris or Eupatorium odoratum and used to cure fresh wounds or cuts (Devkota et al., 2017). The indigenous Pankararu people in the semi-arid of Pernambuco State, Northeast of Brazil, utilize $H$. galactophylla for treating digestive system related problems such as diarrhea and vomiting and for treating epilepsy (LondoñoCastañeda et al., 2017).

\section{COMMON LICHEN SUBSTANCES PRESENT IN HETERODERMIA SPECIES}

Lichens are capable of producing a number of secondary metabolites which apparently do not occur in other organisms. Most of these metabolites are small molecules but are biologically active and exhibit myriad of biological activities. Besides, these metabolites are also useful in the taxonomy of lichens. Thin layer chromatography is one of the most widely used bioanalytical techniques employed to detect lichen substances. Besides, other techniques such as HPLC, column chromatography, liquid chromatography-mass spectrometry and nuclear magnetic resonance spectroscopic methods have been widely employed to detect and to elucidate the structures of lichen substances. Compounds viz. atranorin and zeorin are known to be the signature compounds to be present in Heterodermia species. Besides these compounds, compounds such as norstictic acid and salazinic acid are also present in many of Heterodermia species (Awasthi, 2007; Fazio et al., 2007; Molnár and Farkas, 2010; Honda et al., 2010; Musharraf et al., 2015; Kekuda and Vinayaka, 2016). A list of major secondary metabolites detected in some Heterodermia species is shown in Table 1 and Figure 2 presents structures of some lichen metabolites.

\section{BIOLOGICAL ACTIVITIES OF HETERODERMIA SPECIES}

Lichens are shown to display a variety of pharmacological activities. Several studies have been carried out by researchers to investigate biological activities of crude solvent extracts and purified compounds from Heterodermia species. Literature survey revealed that species of Heterodermia exhibits a range of biological activities such as antimicrobial, antioxidant, antinociceptive, antiinflammatory, immunomodulatory, enzyme inhibitory, cytotoxic, insecticidal and anthelmintic activities.

\section{Antibacterial activity of Heterodermia species}

Studies have shown that solvent extracts and purified compounds from Heterodermia species exhibit antibacterial properties. Ethanol extract of $H$. leucomela was found to inhibit Mycobacterium tuberculosis strains (Gupta et al., 2007). The study carried out by Paudel et al. (2012) revealed the potential of methanol extract of Heterodermia sp. to inhibit Bacillus subtilis. The methanol extract of $H$. diademata was effective in inhibiting Staphylococcus aureus (isolates from burn), Streptococcus mutans (cariogenic isolates), uropathogenic bacteria (Kambar et al., 2014). Extract of $H$. obscurata was effective against gram positive and gram negative bacteria (Kekuda et al., 2015). Solvent extracts of $H$. boryi were shown to inhibit gram positive and gram negative bacteria (Prabhu and Sudha, 2015). Kekuda and Vinayaka (2016) observed anticaries activity exhibited by $H$. leucomela against Streptococcus mutans isolates. Dichloromethane extract of $H$. diademata and $H$. podocarpa was inhibitory to Klebsiella pneumoniae while dichloromethane extract of $H$. leucomelos, $H$. indica and $H$. speciosa was shown to inhibit the growth of Staphylococcus aureus and K. pneumoniae (Jha et al., 2017). Kekuda et al. (2017) revealed inhibition of gram positive and gram negative bacteria by an extract of $H$. incana. In another study by Hengameh and Rajkumar (2017), solvent extracts of $H$. leucomelos were effective in inhibiting gram-positive and gramnegative bacteria. Atranorin and sekikaic acid, isolated from H. obscurata, were shown to display inhibitory activity against bacteria viz. E. coli, B. subtilis and S. typhi (Thadhani et al., 2012).

\section{Antifungal activity of Heterodermia species}

Extracts and isolated constituents from Heterodermia species were shown to display antifungal properties. The aqueous extract obtained from $H$. leucomela was effective in exhibiting antifungal activity against a number of molds including plant pathogenic fungi and dermatophytes in terms of inhibition of spore germination. At $80 \mu \mathrm{l} / \mathrm{ml}$ concentration, 100\% inhibition of germination of spores of all test fungi was observed (Shahi et al., 2001). Acetone, methanol and chloroform extracts of $H$. diademata were shown to exhibit antifungal activity against phytopathogenic fungi such as Aspergillus flavus, A. fumigatus, Alternaria alternata, Fusarium roseum, F. oxysporum, F. solani, Penicillium citrinum (Tiwari et al., 2011). The methanol extract of $H$. diademata was effective in inhibiting Candida albicans, Cryptococcus neoformans, Colletotrichum capsici (Kambar et al., 2014). The methanol extract of $H$. obscurata displayed antifungal activity against $C$. capsici, F. oxysporum, A. alternata and A. flavus (Kekuda et al., 2015). Solvent extracts viz. acetone, methanol and chloroform extracts of $H$. leucomelos were shown to inhibit the growth of $A$. niger, A. flavus, F. oxysporum, F. solani, C. falcatum (Babiah et al., 2015). Extracts of H. comosa were effective against F. solani and F. oxysporum (Shivanna and Garampalli, 2016). The methanol extract of $H$. incana was shown to inhibit mycelial growth of seed-borne fungi (Kekuda et al., 2017). Candida albicans was susceptible to dichloromethane fraction of $H$. indica 
and $H$. diademata (Jha et al., 2017). Atranorin, isolated from hexane extract of $H$. microphylla, is shown to exhibit antifungal activity against Colletotrichum gloeospoioides and C. musae. The compound was effective in inhibition germination of spores of the fungi (Bombuwela et al., 2008). Methyl $\beta$-orcinol carboxylate, derived from atranorin (isolated from $H$. obscurata) was effective in inhibiting yeasts and molds (Thadhani et al., 2012). Solvent extracts of $H$. boryi displayed inhibitory activity against Pestalotia foedans, Phomopsis leptostromiformis var. occidentalis, F. oxysporum, Paeciliomyces variotii (Balasubramanian and Nirmala, 2014a).

Table 1: Major secondary metabolites in various Heterodermia species.

\begin{tabular}{|c|c|c|}
\hline Heterodermia sp. & Compounds detected & References \\
\hline H. squamulosa & Atranorin, zeorin & Wang et al. (2008) \\
\hline H. microphylla & Atranorin, chloroatranorin and zeorin & Bombuwela et al. (2008) \\
\hline H. queensberryi & Atranorin, zeorin & Weerakoon and Aptroot (2014) \\
\hline H. japonica & Atranorin, zeorin, salazinic acid, norstictic acid & Din et al. (2010) \\
\hline H. appendiculata & Atranorin, zeorin, salazinic acid, norstictic acid, chloratranorin & Din et al. (2010) \\
\hline H. leucomela & $\begin{array}{l}\text { Atranorin, zeorin, salazinic acid, glyceryl trilinolate, 6a-hydroxyhop-21bH-22(29)-en, } \\
\text { and 3,6-dimethyl-2-hydroxy-4-methoxybenzoic acid }\end{array}$ & $\begin{array}{l}\text { Devkota (2008), } \\
\text { Kathirgamanathar et al. (2006) }\end{array}$ \\
\hline H. upretii & Atranorin, teloschistin and 7-chloroemodin & Joshi et al. (2014) \\
\hline H. diademata & Atranorin, chloratranorin and zeorin & Behera et al. (2016) \\
\hline H. incana & Atranorin and zeorin & Kekuda et al. (2017) \\
\hline H. obscurata & Atranorin, chloratranorin, zeorin, emodin, 7-chloroemodin & Din et al. (2010) \\
\hline H. albicans & Atranorin, zeorin and salazinic acid & Behera et al. (2016) \\
\hline H. angustiloba & Atranorin, zeorin, salazinic acid and norstictic acid & Behera et al. (2016) \\
\hline H. circinalis & Atranorin, zeorin & Boom et al. (2007) \\
\hline H. granulifera & $\begin{array}{l}\text { Atranorin, chloroatranorin, salazinic acid, zeorin, hypoconstictic acid, consalazinic } \\
\text { acid, norstictic acid, 3-O-methylconsalazinic acid, norhypoconstictic acid }\end{array}$ & Boom et al. (2007) \\
\hline H. magellanica & Atranorin, zeorin & Boom et al. (2007) \\
\hline H. antillarum & Atranorin, zeorin and salazinic acid & Behera et al. (2016) \\
\hline H. flabellata & Atranorin, zeorin, emodin, 7-chloroemodin & Din et al. (2010); Behera et al. (2016) \\
\hline H. isidiophora & Atranorin and zeorin & Behera et al. (2016) \\
\hline H. pseudospeciosa & Atranorin, zeorin, salazinic acid and norstictic acid & Behera et al. (2016) \\
\hline H. punctifera & Atranorin, zeorin and norstictic acid & Devkota (2008) \\
\hline H. speciosa & Atranorin, zeorin & Devkota (2008) \\
\hline H. dissecta & Atranorin, zeorin, salazinic acid and norstictic acid & Devkota (2008) \\
\hline $\begin{array}{l}\text { H. indica, H. albidiflava, } H . \text { boryi, } H . \text { comosa, } \\
\text { H. dactyliza, H. firmula, H. galactophylla, } \\
\text { H. hypochraea, H. hypoleuca, H. lutescens, } \\
\text { H. pellucida, H. togashii, H. tremulans }\end{array}$ & Atranorin, zeorin & Awasthi (2007) \\
\hline $\begin{array}{l}\text { H. awasthii, } H . \text { barbifera, } H \text {. himalayensis, } \\
\text { H. podocarpa, H. propagulifera, } H \text {. rubescens }\end{array}$ & Atranorin, zeorin, salazinic acid, norstictic acid & Awasthi (2007) \\
\hline H. dentrica & Atranorin, salazinic acid, norstictic acid & Awasthi (2007) \\
\hline H. hypocaesia, H. rubricosa & Atranorin, zeorin, salazinic acid & Awasthi (2007) \\
\hline
\end{tabular}

\section{Cytotoxic activity of Heterodermia species}

Methanol extracts of some Heterodermia sp. were investigated for cytotoxicity by brine shrimp lethality assay. Some species were effective in terms of mortality of shrimps with an $\mathrm{IC}_{50}$ value of 100 and $200 \mu \mathrm{g} / \mathrm{ml}$ (Paudel et al., 2012). Recently, dichloromethane fraction from $H$. indica, $H$. leucomela, $H$. diademata, $H$. punctifera, $H$. microphylla, $H$. podocarpa and $H$. speciosa displayed strong cytotoxicity in brine shrimp assay with $>80 \%$ mortality (Jha et al., 2017).

\section{Antioxidant activity of Heterodermia species}

Many Heterodermia species have been investigated for antioxidant activity. Verma et al. (2008b) showed a dose-dependent inhibition of lipid peroxidation by an extract of $H$. podocarpa. Thadhani et al. (2011) isolated compounds viz. methyl orsellinate, methyl haematommate, methyl- $\beta$-orcinolcarboxylate, atranorin, and m-depside sekikiac acid from $H$. obscurata and evaluated their antioxidant activity by in vitro superoxide radical, nitric oxide radical and DPPH radical scavenging assays. The isolated compounds displayed lower scavenging potential when compared to reference antioxidants. Methanol extracts from Heterodermia species were effective in scavenging DPPH and ABTS radicals with marked scavenging potential against DPPH radicals (Paudel et al., 2012). Balasubramanian and Nirmala (2014b) screened 
antioxidant potential of $H$. boryi. The lichen extract was effective in scavenging DPPH and ABTS radicals and caused inhibition of lipid peroxidation and DNA damage. The study of Behera et al. (2016) revealed the antioxidant potential of ethyl acetate extract of Heterodermia species by DPPH and TEAC (Trolox equivalent activity capacity) assays. None of the species except H. pseudospeciosa exhibited an inhibition of DPPH to $>50 \%$. The study of Jha et al. (2017) revealed the potential of $H$. indica, $H$. leucomela $H$. microphylla, and $H$. speciosa to scavenge DPPH radicals.

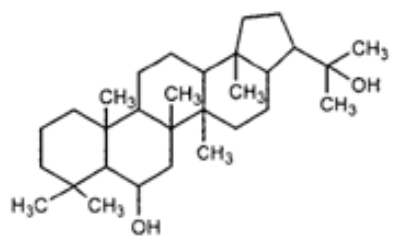

Zeorin<smiles>Cc1cc(O)c2c(c1)C(=O)c1cc(O)c(Cl)c(O)c1C2=O</smiles>

7-chloroemodin<smiles>Cc1cc(O)c2c(c1)C(=O)c1c(O)cc(O)cc1C2=O</smiles>

Emodin<smiles>CC(=O)c1c(C)cc(OC(=O)c2c(C)cc(O)c(CO)c2O)c(C)c1O</smiles>

Atranorin<smiles>Cc1cc(O)c(C=O)c2c1C(=O)Oc1c(C)c(O)c3c(c1O2)C(O)OC3=O</smiles>

Norstictic acid<smiles>CCCCCCCC1C2Oc3cc(OC)cc(C(=O)CCCC)c3C(=O)OC2CC(O)C1C(=O)O</smiles>

Lobaric acid<smiles>Cc1cc(O)c(C=O)c2c1C(=O)Oc1c(CO)c(O)c3c(c1OC2O)C(=O)OC3=O</smiles>

Salazinic acid

Fig. 2: Structures of some lichen substances.

Table 2: Enzyme inhibitory potential of Heterodermia species.

\begin{tabular}{|c|c|c|}
\hline Heterodermia species & Enzyme inhibited & Reference \\
\hline H. leucomela & Amylase & Karthik et al. (2011) \\
\hline H. leucomelos & $\beta$-Glucosidase & Parizadeh and Garampalli (2016) \\
\hline $\begin{array}{l}\text { H. diademata, H. angustiloba, H. albicans, H. flabellata, H. antillarum, } \\
\text { H. isidiophora, H. incana and H. pseudospeciosa }\end{array}$ & Lipoxygenase & Behera et al. (2016) \\
\hline H. leucomelos & Amylase & Hengameh et al. (2016) \\
\hline H. leucomelos & Pancreatic lipase & Shivanna et al. (2017) \\
\hline Heterodermia sp. & Acetyl and butyryl-cholinesterase, phosphodiesterase, $\beta$-glucuronidase & Thadhani et al. (2014) \\
\hline H. podocarpa & Tyrosinase & Verma et al. (2008b) \\
\hline
\end{tabular}

\section{Enzyme inhibitory activity of Heterodermia species}

Studies have shown the potential of some Heterodermia species to inhibit certain enzymes of clinical importance such as amylase, lipase, tyrosinase, and glucosidase. A brief detail on the enzyme inhibitory potential of extracts and purified compounds of Heterodermia species is presented in Table 2 .

\section{Antinociceptive and anti-inflammatory activity of Heterodermia species}

Glucomannan was obtained from successive aqueous and alkaline extraction of the thallus of the lichenized fungus $H$. obscurata. Intra-peritoneal administration of glucomannan resulted in a marked and dose-dependent inhibition of acetic acid- induced visceral pain with an $\mathrm{ID}_{50}$ of $0.6 \mathrm{mg} / \mathrm{kg}$ and inhibition of $88 \pm 4 \%$. It also reduced leukocyte migration indicating the potential utilization of glucomannan against pain and inflammation (Pereira et al., 2010). In another study, glucomannan from $H$. obscurata, was investigated for antinociceptive activity in behavioral models of acute and chronic pain in mice. In the partial sciatic nerve ligation model, the glucomannan was found to reduce the mechanical allodynia and the levels of interleukin 1- $\beta$ (IL-1 $\beta$ ) in spinal cord and nerve. In case of systemic treatment, the polysaccharide inhibited the nociception induced by intraplantar injection of glutamate and by intrathecal injection of N-methyld-aspartic acid, $( \pm)$-1-aminocyclopentane-trans-1,3-dicarboxylic acid, tumour necrosis factor $\alpha$ and IL-1 $\beta$. It was concluded that the 
glucomannan has significant antinociceptive effect in acute and chronic pain (Córdova et al., 2013).

\section{Immunomodulatory activity of Heterodermia species}

Lobaric acid, a compound isolated from Heterodermia sp., was investigated for immunomodulatory activity by Thadhani et al. (2014). The compound was found to exhibit potent oxidative burst inhibitory activity in human polymorphonuclear (PMN) cells. The compound suppressed both the myeloperoxidase dependent and myeloperoxidase independent reactive oxygen species production of PMNs. In another study, compounds viz. methyl orsellinate, methyl haematommate, methyl- $\beta$-orcinolcarboxylate, lobaric acid and atranorin isolated from $H$. obscurata were tested for immunomodulatory effect on the basis of their effect on respiratory burst of human whole blood phagocytes, isolated human polymorphonuclear leukocytes and murine macrophages using luminol or lucigenin-based chemiluminescence probes (Thadhani et al., 2015). Compounds viz. methyl haematomate and methyl orsellinate displayed moderate effect on whole blood and intra-cellular ROS (reactive oxygen species), however, these compounds strongly inhibited extra-cellular ROS with $\mathrm{IC}_{50}$ values $3.3 \pm 0.1 \mu \mathrm{g} / \mathrm{ml}$ and $6.1 \pm 1.0 \mu \mathrm{g} / \mathrm{ml}$, respectively. Lobaric acid was shown to suppress myeloperoxidase dependent and myeloperoxidase independent ROS production in PMNs.

\section{Insecticidal activity of Heterodermia species}

Karthik et al. (2011) determined the insecticidal activity of methanol extract of $H$. leucomela in terms of its larvicidal effect against $2^{\text {nd }}$ and $3^{\text {rd }}$ instar larvae of Aedes aegypti. Among larvae, marked susceptibility was shown by $2^{\text {nd }}$ instar larvae. In another study 3,6-dimethyl-2-hydroxy-4-methoxybenzoic acid, isolated from $H$. leucomelos, was shown to exhibit larvicidal effect against $2^{\text {nd }}$ instar larvae of $A$. aegypti (Kathirgamanathar et al., 2006).

\section{Anthelmintic activity of Heterodermia species}

The study carried out by Prabhu and Sudha (2016) revealed the anthelmintic activity of various solvent extracts viz. aqueous, methanol, petroleum ether, acetone and chloroform extract of $H$. boryi. The extracts were effective in causing paralysis and death of adult Indian earthworm (Pheretima posthuma) in a dose-dependent manner. Acetone and methanol extracts displayed significant anthelmintic activity at the highest concentration tested.

\section{CONCLUSIONS}

An extensive literature survey carried out resulted in potential biological properties of Heterodermia species. Compounds such as atranorin, zeorin, salazinic acid and norstictic acid are common in many species of Heterodermia. The presence of these secondary metabolites might be attributed to the various biological activities displayed by Hetereodermia species. Isolation of mycobiont and their mass cultivation for the purpose of obtaining bioactive metabolites should be considered to exploit the lichens for commercial purpose.

\section{SOURCES OF SUPPORT}

None.

\section{CONFLICTS OF INTEREST}

Author declare there are no conflict of interest.

\section{REFERENCES}

Awasthi DD. A compendium of the macrolichens from India, Nepal and Sri Lanka, Bishen Singh Mahendra Pal Singh, Dehra Dun, India, 2007.

Babiah PS, Upreti DK, John SA. Assessment of fungicidal potential of lichen Heterodermia leucomelos (L.) Poelt against pathogenic fungi. Current Research in Environmental \& Applied Mycology, 2015; 5(2):92-100.

Balasubramanian M, Nirmala P. Antimycobacterial activity of foliose lichens on plant and animal pathogens. International Journal of Pharmaceutical Sciences and Research, 2014a; 5(11):4825-4831.

Balasubramanian M, Nirmala P. Evaluation of anti-oxidant properties of Foliose lichens. Journal of Chemical and Pharmaceutical Research, 2014b; 6(9):177-184.

Behera BC, Morey MV, Gaikwad SB. Anti-lipoxygenase, radical scavenging and antimicrobial activities of lichen species of genus Heterodermia (Physciaceae). Botanica Pacifica, 2016; 5(1):79-85.

Bombuwela K, Kathirgamanathar S, Thadhani V, Jayalal RGU, Adikaram NKB, Wijesundara DSA, Andersen R, Wolseley P, Karunaratne V. Chemistry of Heterodermia microphylla, a lichen new to Sri Lanka. J Natn Sci Foundation Sri Lanka, 2008; 36(3):251-252.

Boom PVD, Elix J, Sipman H. New or interesting lichen records from Guatemala I. Willdenowia, 2007; 37:363-375.

Brisdelli F, Perilli M, Sellitri D, Piovano M, Garbarino JA, Nicoletti M, Bozzi A, Amicosante G, Celenza G. Cytotoxic activity and antioxidant capacity of purified lichen metabolites: an in vitro study. Phytother Res, 2013; 27(3):431-437.

Córdova MM, Martins DF, Silva MD, Baggio CH, Carbonero ER, Ruthes AC, Iacomini M, Santos AR. Polysaccharide glucomannan isolated from Heterodermia obscurata attenuates acute and chronic pain in mice. Carbohydr Polym, 2013; 92(2):2058-64.

Devkota A. Taxonomic study of lichens of Phulchowki hills, Lalitpur district (Kathmandu valley). Scientific World, 2008; 6(6):44-51.

Devkota S, Chaudhary RP, Werth S, Scheidegger C. Indigenous knowledge and use of lichens by the lichenophilic communities of the Nepal Himalaya. Journal of Ethnobiology and Ethnomedicine, 2017; 13(1):15.

Din LB, Zakaria Z, Samsudin MW, Elix JA. Chemical profile of compounds from lichens of Bukit Larut, Peninsular Malaysia. Sains Malaysiana, 2010; 39(6):901-908.

Fazio AT, Adler MT, Bertoni MD, Sepulveda CS, Damonte EB, Maier MS. lichen secondary metabolites from the cultured lichen mycobionts of Teloschistes chrysophthalmus and Ramalina celastri and their antiviral activities. Z Naturforsch, 2007; 62c:543-549.

Gunathilaka PADHN, Ranundeniya RMNS, Najim MMM, Seneviratne S. A determination of air pollution in Colombo and Kurunegala, Sri Lanka, using energy dispersive X-ray fluorescence spectrometry on Heterodermia speciosa. Turkish Journal of Botany, 2011; 35:439-446.

Gupta VK, Darokar MP, Saikia D, Pal A, Fatima A, Khanuja SPS. Antimycobacterial activity of lichens. Pharmaceutical Biology, 2007; 45(3):200-204.

Hengameh P, Rajkumar GH. Assessment of bactericidal activity of some lichen extracts by disc diffusion assay. Int J Drug Dev \& Res, 2017; 9(1):9-19.

Hengameh P, Rashmi S, Rajkumar HG. In vitro inhibitory activity of some lichen extracts against $\alpha$-amylase enzyme. European Journal of Biomedical and Pharmaceutical Sciences, 2016; 3(5):315-318.

Honda NK, Pavan FR, Coelho RG, Leite ASR, Micheletti AC, Lopes TIB, Misutsu MY, Beatriz A, Brum RI, Leite CQF. Antimycobacterial activity of lichen substances. Phytomedicine, 2010; 17:328-332.

Jha BN, Shrestha M, Pandey DP, Bhattarai T, Bhattarai HD, Paudel B. Investigation of antioxidant, antimicrobial and toxicity activities of lichens from high altitude regions of Nepal. BMC Complementary and Alternative Medicine, 2017; 17:282.

Joshi Y, Upadhyay S, Chandra K. Heterodermia upretii, a new species from India (Physciaceae, Ascomycota). Phytotaxa, 2014; 175(2):117-120. 
Kambar Y, Vivek MN, Manasa M, Vinayaka KS, Mallikarjun N, Kekuda PTR. Antimicrobial activity of Leptogium burnetiae, Ramalina hossei, Roccella montagnei and Heterodermia diademata. International Journal of Pharmaceutical and Phytopharmacological Research, 2014; 4(3):164-168.

Karthik S, Nandini KC, Kekuda PTR, Vinayaka KS, Mukunda S. Total phenol content, insecticidal and amylase inhibitory efficacy of Heterodermia leucomela (L). Annals of Biological Research, 2011; 2(4):3843.

Karunaratne V, Bombuwela K, kathirgamanathar S, Thadhani VM. Lichens: A chemically important biota. J Natn Sci Foundation Sri Lanka, 2005; 33(3):169-186.

Kathirgamanathar S, Ratnasooriya WD, Baekstrom P, Andersen RJ, Karunaratne V. Chemistry and bioactivity of Physciaceae lichens Pyxine consocians and Heterodermia leucomelos. Pharmaceutical Biology, 2006; 44(3):217-220.

Kekuda PTR, Raghavendra HL, Vinayaka KS. Antimicrobial activity of Heterodermia incana (Stirt.) D.D. Awasthi. International Journal of Green Pharmacy, 2017; 11(Suppl 3):S568-S574.

Kekuda PTR, Ranjitha MC, Firdose G, Vidya P, Vinayaka KS Antimicrobial activity of selected corticolous lichens. Science, Technology and Arts Research Journal, 2015; 4(3):169-174.

Kekuda PTR, Vinayaka KS. In vitro anticaries activity of some macrolichens of Karnataka, India. International Journal of Pharma Research and Health Sciences, 2016; 4(3):1244-1248.

Kumar B. Assessment of lichen species in a temperate region of Garhwal Himalaya, India. The Journal of American Science, 2009; 5(4):107-112.

Londoño-Castañeda PA, Buril MLL, Rego-Cunha IP, Silva NH, Honda NK, Pereira EC, Andrade LHC. Lichens used in the traditional medicine by the Pankararu Indigenous community, Pernambuco-Brazil. Global Journal of Science Frontier Research: C Biological Science, 2017; 17(4):15-22.

Luckling R, del Prado R, Lumbsch TH, Will-Wolf S, Aptroot A, Sipman HJM, Umana L, Chaves JL. Phylogenetic patterns of morphological and chemical characters and reproductive mode in the Heterodermia obscurata group in Costa Rica (Ascomycota, Physciaceae). Systematics and Biodiversity, 2008; 6(1):31-41.

Molnár K, Farkas E. Current results on biological activities of lichen secondary metabolites: a review. Z Naturforsch C, 2010; 65(34):157-173.

Müller K. Pharmaceutically relevant metabolites from lichens. Appl Microbiol Biotechnol, 2001; 56(1-2):9-16.

Musharraf SG, Kanwal N, Thadhani VM, Choudhary IM. Rapid identification of lichen compounds based on the structure-fragmentation relationship using ESI-MS/MS analysis. Anal Methods, 2015; 7:6066-6076.

Nguyen KH, Chollet-Krugler M, Gouault N, Tomasi S. UVprotectant metabolites from lichens and their symbiotic partners. Nat Prod Rep, 2013; 30(12):1490-1508.

Oksanen I. Ecological and biotechnological aspects of lichens. Appl Microbiol Biotechnol, 2006; 73:723-734.

Parizadeh H, Garampalli RH. Evaluation of some lichen extracts for $\beta$-Glucosidase inhibitory as a possible source of herbal anti-diabetic drugs. American Journal of Biochemistry, 2016; 6(2):46-50.

Paudel B, Bhattarai HD, Pandey DP, Hur JS, Hong SG, Kim I, Yim JH. Antioxidant, antibacterial activity and brine shrimp toxicity test of some mountainous lichens from Nepal. Biol Res, 2012; 45:387-391.

Pereira MI, Ruthes AC, Carbonero ER, Marcon R, Baggio CH, Freitas CS, Santos AR, Eliasaro S, Sassaki GL, Gorin PA, Iacomini M. Chemical structure and selected biological properties of a glucomannan from the lichenized fungus Heterodermia obscurata. Phytochemistry, 2010; 71(17-18):2132-2139.

Pinokiyo A, Singh KP, Singh JS. Leaf-colonizing lichens: their diversity, ecology and future prospects. Current Science, 2006; 90(4):509518

Prabhu SS, Sudha SS. Evaluation of the antibacterial properties of some lichen species against human pathogens. International Journal of Advanced Research in Biological Sciences, 2015; 2(4):177-181.

Prabhu SS, Sudha SS. In vitro study on anthelmintic activity of Heterodermia boryi macrolichen collected from the Nilgiris, Tamilnadu, India. Int J Curr Microbiol App Sci, 2016; 5(9):764-768.

Rawat S. North West region of Nanda Devi biosphere reserves, Garhwal Himalaya with unexplored lichen wealth and its medicinal lichen distribution in different aspect. New York Science Journal, 2016; 9(9):28 40.

Reddy RG, Veeraval L, Maitra S, Chollet-Krugler M, Tomasi S, Dévéhat FL, Boustie J, Chakravarty S. Lichen-derived compounds show potential for central nervous system therapeutics. Phytomedicine, 2016; 23(12):1527-1534

Rodríguez AOE, Andrade BW, Díaz LF, Celis C, Ortiz-Ardila A. Quantification of heavy metals in lichens from the upper basin of the river Bogotá. Pharmacologyonline, 2016; 2:21-27.

Russo A, Caggia S, Piovano M, Garbarino J, Cardile V. Effect of vicanicin and protolichesterinic acid on human prostate cancer cells: role of Hsp70 protein. Chem Biol Interact, 2012; 195(1):1-10.

Sanders WB. Lichens: The interphase between Mycology and Plant morphology. BioScience, 2001; 51(12):1025-1036.

Shah NC. Lichens of commercial importance in India. The Scitech Journal, 2014; 1(2):32-36.

Shahi SK, Shukla AC, Dikshit A, Upreti DK. Broad spectrum antifungal properties of the lichen Heterodermia leucomela. The Lichenologist, 2001; 33:177-179.

Shivanna R, Garampalli RH. Investigation of macrolichens for antifungal potentiality against phytopathogens. Indo American Journal of Pharmaceutical Research, 2016; 6(4):5290-5296.

Shivanna R, Parizadeh H, Garampalli RH. Invitro anti-obesity effect of macrolichens Heterodermia leucomelos and Ramalina celastri by pancreatic lipase inhibitory assay, Int J Pharm Pharm Sci, 2017; 9(5):137140.

Singh S, Upreti DK, Lehri A, Paliwal AK. Quantification of lichens commercially used in traditional perfumery industries of Uttar Pradesh, India. Indian Journal of Plant Sciences, 2015; 4(1):29-33.

Spribille T, Thor G, Bunnell FL, Goward T, Bjork CR. Lichens on dead wood: species-substrate relationships in the epiphytic lichen floras of the Pacific Northwest and Fennoscandia. Ecography, 2008; 31:741-750.

Stocker-Wörgötter E. Metabolic diversity of lichen-forming ascomycetous fungi: culturing, polyketide and shikimate metabolite production, and PKS genes. Nat Prod Rep, 2008; 25(1):188-200.

Thadhani VM, Choudhary IM, Khan S, Karunaratne V. Antimicrobial and toxicological activities of some depsides and depsidones. J Natn Sci Foundation Sri Lanka, 2012; 40(1):43-48.

Thadhani VM, Choudhary MI, Ali S, Omar I, Siddique H, Karunaratne V. Antioxidant activity of some lichen metabolites. Nat Prod Res, 2011; 25(19):1827-1837.

Thadhani VM, Mesaik AM, Asif M, Karunaratne V, Choudhary IM. Immunomodulatory activities of some common lichen metabolites. Int J Pharm Pharm Sci, 2015; 7(11):144-147.

Thadhani VM, Naaz Q, Choudhary IM, Mesaik AM, Karunaratne V. Enzyme inhibitory and immunomodulatory activities of the depsidone lobaric acid extracted from the lichen Heterodermia sp. J Natn Sci Foundation Sri Lanka, 2014; 42(2):193-196.

Tiwari P, Rai H, Upreti DK, Trivedi S, Shukla P. Assessment of antifungal activity of some Himalayan foliose lichens against plant pathogenic fungi. American Journal of Plant Sciences, 2011; 2:841-846.

Upreti DK, Divakar PK, Nayaka S. Commercial and ethnic use of lichens in India. Economic Botany, 2005; 59(3):269-273.

Verma N, Behera BC, Makhija U. Antioxidant and hepatoprotective activity of a lichen Usnea ghattensis in vitro. Appl Biochem Biotechnol, 2008a; 151(2-3):167-181.

Verma N, Behera BC, Sonone A, Makhija U. Lipid peroxidation and tyrosinase inhibition by lichen symbionts grown in vitro. African Journal of Biochemistry Research, 2008b; 2(12):225-231. 
Vinayaka KS, Krishnamurty YL. Ethno-lichenological studies of Shimoga and Mysore districts, Karnataka, India. Advances in Plant Sciences, 2012; 25(1):265-267.

Wang XY, Hur H, Lee YM, Koh YJ, Hur J. First Report of Heterodermia squamulosa (Lichenized Ascomycota, Physciaceae) in South Korea. Mycobiology, 2008; 36(3):190-192.

Weerakoon G, Aptroot A. Over 200 new lichen records from Sri Lanka, with three new species to science. Cryptogamie, Mycologie, 2014; 35(1):51-62.

Wei XL, Luo H, Koh YJ, Hur JS. A taxonomic study of Heterodermia (Lecanorales, Ascomycota) in South Korea based on phenotypic and phylogenetic analysis. Mycotaxon, 2008; 105:65-78.
White PAS, Oliveira RCM, Oliveira AP, Serafini MR, Araujo AAS, Gelain DP, Moreira JCF, Almeida JRGS, Quintans JSS, QuintansJunior LJ, Santos MRV. Antioxidant activity and mechanisms of action of natural compounds isolated from lichens: A systematic review. Molecules, 2014; 19:14496-14527.

\section{How to cite this article:}

Kekuda TRP, Vinayaka KS, Sachin MB. Chemistry, ethnobotanical uses and biological activities of the lichen genus Heterodermia Trevis. (Physciaceae; Lecanorales; Ascomycota): A comprehensive review. J App Pharm Sci, 2018; 8(05): 148-155. 